Journal of Qualitative Criminal Justice \& Criminology

\title{
Historical Book Review | The Professional Thief
}

\author{
Jurg Gerber ${ }^{1}$
}

${ }^{1}$ Sam Houston State university

Published on: Apr 01, 2014

License: Creative Commons Attribution 4.0 International License (CC-BY 4.0). 
Edwin H. Sutherland. The Professional Thief. University of Chicago Press, 1937; 257 pp.; ISBN: 0226780511.

\section{Introduction}

Perhaps because he was the son of a minister and raised in a very traditional home (Geis \& Meier, 1977, p. 24), Edwin Sutherland (1883-1950) had a populist streak and is known for two major contributions to American criminology: the theory of differential association (DA) and the concept of white collar crime (WCC). His classic book entitled The Professional Thief is at the intersection of these two interests, although its influence has been more acknowledged with respect to DA than WCC. This review traces scholarly reactions to the book and its enduring contributions to American criminology.

\section{Summary of the book and previous reviews}

This book consists of two parts; the first eight chapters were apparently written by the thief Chic Conwell (aka Broadway Jones) and represent an account of the world of theft at a particular time in American history. It is a highly entertaining, descriptive, and folksy account of a social milieu. The last two chapters were written by Sutherland; he uses these chapters to establish the criminological context for the book.

The Professional Thief is a book that has been in print for nearly 80 years and has already been discussed, reviewed, praised, and critiqued many times. By October 2014, it had been cited 878 times in Google Scholar (retrieved October 27, 2014), which re-enforces Vasoli and Terzola's (1974, p. 132) assessment that "one can scarcely open a modern criminology text which does not in some way pay homage to Conwell's fascinating reminiscences and Sutherland's annotative and interpretive supplements to them."

As is so often the case with a book that has been published many decades ago, the earlier reviews and discussions are more positive than the more recent ones. This fact can be expected, for with the passage of time, novelty wears off, empirical reality changes, and new theoretical perspectives and methodologies are developed. A work that has once been at the cutting edge of a field becomes more run of the mill. A book review published in 1937, the year Thief was published, was very positive:

The reader of The Professional Thief gets the impression that the book is to a certain extent the joint product of a man well versed in the practical experiences of crime and a man well versed in the general field of criminal behavior. (Locke, 1937, p. 186)

The reviewer saw the concept of professionalism as a positive contribution to the criminological literature (it was a time when most criminologists studied the urban underclass as the source of all 
crime, but did not give a voice to criminals).

Snodgrass (1973) was considerably more critical than Locke (1937) had been. Among other issues, Snodgrass accused Sutherland of not knowing Conwell particularly well; furthermore, he accused him of falsifying some issues in Conwell's past in order to protect the latter's identity. Around the same time, Vasoli and Terzola (1974) published a detailed and fairly criti cal analysis of the book, in which they questioned Sutherland and Conwell's methodology and substantive findings: "Sutherland's annotations in combination with Conwell's text provide at best a narrow view of professional theft" ( $\mathrm{p}$. 149).

\section{Enduring themes and contributions}

What are the enduring themes and contributions of this work? This is particularly a relevant question as "the bulk of Conwell's experiences and observations describe the state of the profession between 1905 and 1925" (Vasoli \& Terzola, 1974, p. 134). Clearly the terminology used is archaic and, as Vasoli and Terzola (1974) argued, the rackets that Sutherland had identified did not exist any longer in the 1970s. The substantive contributions that the book made to the study of theft are at best marginal in the early 21st Century, and likely non-existent. However, there are some enduring contributions.

\section{White-collar crime v. street crime and differential association}

Sutherland's two major contributions to American criminology are the theory of differential association (developed in his text book that has been published in 11 editions between 1924 and 1992: Sutherland, 1924; Sutherland, Cressey, \& Luckenbill, 1992) and the concept of white-collar crime (Sutherland, 1940; 1949). His theory of differential association was developed, in part, by his publications on white-collar crime and The Professional Thief. In essence, he looked at crime in the streets and the suites to develop a theory that was not dependent on low socioeconomic status, what was referred to at that time as feeble-mindedness, or biology, the prevailing explanations of the day. However, whereas he made contributions to both fields, it seems very clear in retrospect that he respected the professional thieves for their honesty to identify themselves as criminals, while whitecollar offenders had a non-criminal self-concept:

It becomes evident that in some ways Sutherland came to admire and glamorize the professional thief and to loathe the white-collar offender, a loathing that translated into his claim that businessmen are the most subversive force in America and his equating of the advertising tactics of the power and light utilities with the propaganda of the German Nazis. (Geis \& Meier, 1977, p. 25)

Although the theory of differential association could have been developed without the publication of The Professional Thief, it is undoubtedly the case that this book, along with books such as Cressey's Other People's Money (1953), contributed to the rising popularity of sociological approaches among 
criminologists. Generations of researchers have been able to rely on the sociological foundations Sutherland built, both theoretical and substantive, for their work. The Professional Thief directed attention away from fairly crude biological theories of the day and explanations that blamed the urban underclass and recent immigrants for the crime problem.

\section{Qualitative methods}

A debate has been raging in criminology over the relative merits of quantitative v. qualitative research. This forum is not appropriate to rehash the various arguments, especially since Sutherland contributed to both research traditions. However, it is clear that The Professional Thief relied on the research approach of life histories (Wright, 2005). This approach has been used heavily by qualitative researchers who would be well advised to consult this study for guidance. This is not to say that there are no problems with this study; Sutherland has been criticized that he was very selective in his reporting:

Even worse, speculation has surfaced that Sutherland misrepresented certain details ... Broadway Jones was heavily addicted to narcotics; Sutherland downplayed this part of his biography... Sutherland insisted on the highest level of academic integrity among scholars towards whom he was critical (the Gluecks, Hooton, and Sheldon); the idea that he may have violated these same standards suggests a troubling hypocrisy. (Wright, 2005, p. 1629)

However, in some ways he was ahead of his time. The term data triangulation was not in vogue during the 1930s, but Sutherland tried to verify Conwell's experiences by relying on a variety of sources including other thieves, two former police officers, and accounts in the popular press. As is so often the case, when researchers develop new techniques (or, in case of quantitative research, new statistical analyses), they make mistakes. However, subsequent researchers can learn from them and improve on their work, but should not forget to give credit where credit is due.

\section{Convict criminology}

Perhaps the most surprising contribution of The Professional Thief is to the relatively newly defined field of convict criminology:

Convict Criminology represents the work of convicts or ex-convicts, in possession of a Ph.D. or on their way to completing one, or enlightened academics and practitioners, who contribute to a new conversation about crime and corrections...The convict scholars are able to do what many previous researchers could not; merge their past with their present and provide a provocative approach to the academic study of their field. The convict criminology perspective is also based on perceptions, experiences, and analytical ideas that originate with defendants and prisoners, and are then developed by critical scholars. (Convictcriminology.com) 
Academic criminology has been the domain of predominantly White, male, and middle class scholars. Other viewpoints have been underrepresented. It was not until the appearance of New Criminology that voices of the previously silent have been heard: women, ethnic and racial minorities, victims, and offenders. What is noteworthy is that the very people who live crime and are the frontline participants of the criminal scene, the offenders, are often not heard in the academic discourse. Sutherland let Chic Conwell speak for himself and introduced a new and different criminology. What had been a relatively sterile academic enterprise became messy, but also more real (to use methodological terminology, the reliability of measures decreased, but their validity probably increased). Modern criminological approaches such as convict criminology owe a debt of gratitude to Chic Conwell and to Sutherland. The latter practiced convict criminology before convict criminology became cool.

\section{Crime as craft or work}

It is in vogue to consider criminals as relatively unskilled, not very reflective or self-aware, not capable of planning, and not concerned with the long range consequences of their acts. While this characterization may be accurate for some criminals, others clearly do not display these personality characteristics. There are some crimes that require their perpetrators to achieve skills and the honing of techniques. Forging documents or embezzling money may be committed by relatively unskilled amateurs, but they are likely to be caught relatively quickly. Forging documents or embezzling money successfully may be very different, requiring skill, planning, and consideration of long range consequences. The criminal reality that Chic Conwell (and, by implication, Sutherland) faced may be very different from the reality of street crime today, but the idea of crime as work or craft is found today in other criminal realms.

As Steinmetz (2015) pointed out, hacking is one such realm. Similar to Sutherland's thief, a hacker becomes one when s/he has mastered skills and is recognized as a hacker by others with that specific brand of expertise:

Regardless of the domain in which one hacks, the honing and exercising of skill is characteristic. Just as Sutherland (1937, p. 14) states that 'a thief is not a professional until he is proficient,' a person is not a hacker until they are skilled. By and large, acts which do not stem from a degree of skill are not considered hacking. (Steinmetz, 2015, p. 132)

\section{Cultural criminology}

In a related vein, cultural criminology (e.g., Ferrell, 1993) owes a debt of gratitude to Sutherland. The Professional Thief is an early example of cultural criminology:

Cultural criminology is a theoretical, methodological and interventionist approach to the study of crime and deviance that places criminality and its control in the context of culture; that is, it views crime and the agencies and institutions of crime control as cultural products-as creative 
constructs. As such they must be read in terms of the meanings they carry. Furthermore, cultural criminology seeks to highlight the interaction between two key elements: the relationship between cultural constructions upwards and cultural constructions downwards. Its focus is always upon the continuous generation of meaning around interaction; rules created, rules broken, a constant interplay of moral entrepreneurship, political innovation and transgression. (Cultural Criminology, 2014)

Cultural criminology studies the meaning of crime in its cultural context. The Professional Thief sets the world of theft in its cultural milieu, beyond which it loses most of its meaning. Although the specific findings are no longer relevant, the approach still is. Similar to convict criminology, Sutherland practiced cultural criminology before cultural criminology was developed.

\section{Conclusion}

There is a tendency not to pay tribute to who has gone before us. Criminological research of yesteryear is seen as outdated and no longer relevant. Contemporary researchers either have to reinvent the wheel, commit errors that others before them have committed ("Those who cannot remember the past are condemned to repeat it"-Santayana, 1905, p. 284), or fancy themselves as having invented or created an approach, methodology, or idea. Sutherland's book The Professional Thief may not be relevant in terms of its actual substance (the world of theft), but as this review demonstrates, his book is an early forerunner of contemporary criminological approaches. To paraphrase Sir Isaac Newton's famous quote, criminologists should consider saying, "If I have seen further, it is by standing on the shoulders of one of our giants, Sutherland."

\section{References}

Convictcriminology.com. (2014). About us. Retrieved November 7, 2014 from

convictcriminolog.com/about.

Cressey, D. R. (1953). Other people’s money. Glencoe, IL: Free Press.

Cultural Criminology. (2014). Retrieved November 7, 2014 from http://

blogs.kent.ac.uk/culturalcriminology.

Ferrell, J. (1993). Crimes of style: Urban graffiti and the politics of criminality. New York, NY: Garland.

Geis, G., and Meier, R. F. (1977). What is "White-Collar Crime"? In G. Geis \& R.F. Meier (eds.) Whitecollar crime: Offenses in business, politics, and the professions (revised edition) (pp. 23-28). New York, NY: Free Press.

Jacques, S., and Wright, R. (2012). Ironies of crime, control, and criminology. Critical Criminology, 20, 153-167. 
Locke, H. (1937). Review of The Professional Thief, Edwin H. Sutherland. Indiana Law Journal 13(2), 184186.

Santayana, G. (1905). The Life of Reason: Reason in Common Sense. New York: Charles Scribner's Sons.

Snodgrass, J. (1973). The criminologist and his criminal: Edwin H. Sutherland and Broadway Jones. Issues in Criminology, 8(1): 1-17.

Steinmetz, K. F. (2015). Craft(y)ness: An ethnographic study of hacking. British Journal of Criminology, $55,125-145$

Sutherland, E. H. (1924). Criminology. Philadelphia, PA: J. B. Lippincott. Sutherland, E. H. (1937). The professional thief. Chicago, IL: University of Chicago Press.

Sutherland, E. H. (1939). White collar criminality. American Sociological Review, 5, 1-12.

Sutherland, E. H. (1949/1983). White collar crime: The uncut version. New Haven, CT: Yale University Press.

Sutherland, E. H., Cressey, D. R., \& Luckenbill, D. F. (1992). Principles of criminology (11th ed.). Lanham, MD: AltaMira Press.

Vasoli, R. H., \& Terzola, D. A.. (1974). Sutherland's professional thief. Criminology, 12, 131-154.

Wright, R. A. (2005). Sutherland, Edwin H. In R. A. Wright \& J. M. Miller (Eds.) Encyclopedia of Criminology (pp. 1926-1929). New York, NY: Routledge. 